\title{
Relationship Between $\beta$-Catenin Expression and Prognostic Parameters of Colorectal Carcinomas
}

\section{$\beta$-Catenin Ekspresyonunun Kolorektal Karsinomlarda Prognostik Parametreler ile iliş̧kisi}

\author{
Kemal PEKER ${ }^{1}$, Mahmut BAŞOĞLU² ${ }^{2}$ Nesrin GÜRSAN³ \\ 'Department of General Surgery, Erzincan University, Faculty of Medicine, ERZINCAN, TURKEY \\ Department of ${ }^{2}$ General Surgery and ${ }^{3}$ Pathology, Atatürk University, Faculty of Medicine, ERZURUM, TURKEY
}

\begin{abstract}
Objective: Colorectal carcinomas are the most frequent tumors of the gastrointestinal tract. $\beta$-catenin, which is related to cadherins, is a cytoplasmic protein responsible for intercellular adhesion. It is also an important component in the Wnt signal pathway. Recent studies have shown structural alterations in the APC gene and axin in patients with colorectal carcinoma, along with $\beta$-catenin. We aimed to compare $\beta$-catenin expression, which is a prognostic factor itself, with other prognostic parameters.
\end{abstract}

Material and Method: A total of 70 patients who had surgical intervention for colorectal malignancies between January 1994 and December 2003 were included in the study. Fifty-nine of the patients $(84.3 \%)$ were male, 11 of the patients $(15.7 \%)$ were female; their ages varied between 24 and 82 (mean $60.3 \pm 15.2$ ) years. Paraffin blocks were immunohistochemically stained for $\beta$-catenin. The number of stained cell nuclei was assessed according to the stage of disease using the TNM classification, histological grade, lymphatic invasion, vascular invasion and tumor's local invasion.

Results: When groups constituted according to tumor histologic grade were compared for prognostic parameters in terms of stain density for $\beta$-catenin and number of stained cell nuclei, stain density was mild $(+)$ and the number of stained nuclei was smaller in well-differentiated groups while stain density was strong $(+++)$ and the number of stained nuclei was higher in poorly differentiated groups. There was a relation between $\beta$-catenin expression and differentiation grade, lymph node metastasis, stage and tumor size but not with vascular invasion.

Conclusion : These data indicate that $\beta$ - catenin, with functions in cell homeostasis and relations with the APC gene, has a substantial role in colorectal carcinogenesis.

Key Words: $\beta$-catenin, Cancer, Colorectal carcinomas

\section{ÖZ}

Amaç: Kolorektal karsinomlar gastrointestinal sistemin en sik görülen tümörleridir. Beta-catenin, kadherinlerle ilişkili, hücreler arası adezyonda görevli sitoplazmik bir proteindir. Aynı zamanda Wnt sinyal yolağının da önemli bir komponentidir. Son dönem çalışmalarında kolorektal karsinomlu hastalarda, supressör APC geni ve axin ile birlikte beta-katenin yapısında da bozulmalar olduğu gösterilmiştir. Bu çalışmada, kolorektal karsinomlarda bir prognostik faktör olan $\beta$-katenin ekspresyonunu, diğer prognostik parametrelerle karşılaştırmayı amaçladık.

Gereç ve Yöntem: Çalışmaya 1994 -2003 yılları arasında kolorektal karsinom tanısı ile opere edilmiş olan 70 hasta dâhil edildi. Hastaların 59'u (\%84,3) erkek, 11'i (\%15,7)' si kadın olup yaşları 24 ile 82 (ortalama 60,3 $\pm 15,2$ ) yıl arasında değişmekteydi. Parafin bloklardan hazırlanan kesitlere beta-katenin antikoru immünohistokimyasal olarak uygulandı. TNM sınıflamasına göre tümörün diferansiasyon derecesi, evresi, lenf nodu metastazı, vasküler invazyon ve tümörün lokal yayılımı ile boyanan nükleus sayısı arasında değerlendirme yapild1.

Bulgular: Tümörün histolojik derecesine göre oluşturulan grupların, $\beta$-katenin ile boyanma şiddetleri ve pozitif boyanan nükleus sayıları, prognostik parametreler ile karşılaştırıldığında; iyi diferansiasyon gösteren gruplarda boyanma şiddeti hafif $(+)$, pozitif boyanan nükleus sayıları daha az iken, kötü diferansiyasyon gösteren gruplar da boyanma şiddetli $(+++)$ ve pozitif boyanan nükleus sayısı daha fazla olarak tespit edildi. Beta-katenin ekspresyonu prognostik parametre olan diferansiyasyon derecesi, lenf dügüumü metastazı, evre ve boyut ile ilişkili bulunurken, damar invazyonu ile ilişkisiz bulundu.

Sonuç: Tüm bu bilgiler ıșığında, beta-katenin’in hücredeki fonksiyonları ve APC geni ile olan ilişkileri nedeniyle kolorektal karsinogenezde önemli bir rolü olduğu açıktır.

Anahtar Sözcükler: $\beta$ - katenin, Kanser, Kolorektal karsinomlar
(Turk Patoloji Derg 2013, 29:87-93)

Received : 22.04.2012 Accepted : 05.02.2013
Correspondence: Kemal PEKER

Erzincan Üniversitesi Tip Fakültesi, Genel Cerrahi Anabilim Dalı, ERZINCAN, TURKEY

E-mail: k.peker@yahoo.com.tr Phone: +90 5359368528 


\section{INTRODUCTION}

Colorectal carcinoma (CRC) is the most common tumors of the gastrointestinal system and has the third highest prevalence in females and males except skin tumors in the United States. Rectal cancers are more common in males while colon cancer is more common in females (1). CRC incidence varies by region and community. This variability is due to differences of dietary and environmental factors. Epidemiological studies have found CRC to be more common in communities with a high fat and low fiber diet with the risk also increasing in communities migrating from low-risk regions to high-risk regions (2,3). Hereditary characteristics seem to be important regarding the age of CRC onset. CRC usually develops before the age of 40 in patients with syndromes showing strong hereditary transmission such as hereditary colon cancer without polyposis and familial polyposis coli (FAP) and hereditary non-polyposis colorectal cancer (HNPCC). The disease usually reaches its highest incidence at the age of 60-70 years in sporadic colon cancer cases without a strong hereditary feature $(4,5)$.

$\beta$-catenin is a cytoplasmic molecule associated with cadherins $(6,7)$. Cytoplasmic $\beta$-catenin levels are normally controlled by a multiprotein complex of genes associated with the suppressor APC genes. Destruction of this complex results in phosphorylation of $\beta$-catenin. The Wnt signaling pathway inactivates degradation of this complex, leading to $\beta$-catenin stabilization. Acquired mutations in the Wnt signaling pathway cause continuous stimulation of this signaling pathway and result in CRC with uncontrolled epithelial cell proliferation $(8,9)$. APC gene mutations are observed in $80 \%$ of CRC cases and this has first been defined in FAP patients $(10,11)$. However, many in vivo studies have revealed APC gene inactivation to result in adenoma development $(12,13)$. We aimed to correlate the expression of the CRC prognostic factor $\beta$-catenin with prognostic parameters in this study.

\section{MATERIAL and METHOD}

A total of 70 patients operated on between 1994 and 2003 were included in the study. There were 59 (84.3\%) males and $11(15.7 \%)$ females aged between 24 and 83 years (mean $60.3 \pm 15.2$ years). Patients who received chemotherapy and/or radiotherapy prior to surgery were excluded from the study as they could lead to an incorrect evaluation. The records of the 70 identified patients were retrospectively analyzed. Tumor stage, histological grade, lymph node metastasis, vascular invasion, and tumor size were determined according to the TNM classification.
Four-micron-thick sections were taken from paraffin blocks obtained from tissues fixed in 10\% formalin for all patients. These sections were deparaffinized in xylene and dehydrated in ethanol series. They were incubated with 3\% $\mathrm{H}_{2} \mathrm{O}_{2}$ for 10 minutes. They were then washed with distilled water and antigen was applied for a total of 20 minutes with one minute intervals every five minutes in Target Retrieval Solution (diluted 1/10) at $750 \mathrm{~W}$. After waiting at room temperature for 20 minutes, they were washed with distilled water. The samples were then kept in PBS (phosphatebuffered saline) for five minutes. They were next incubated for one hour with $1 / 200$ diluted $\beta$-catenin antibody (DAKO). Antibodies were purified and kept in PBS for 10 minutes. After 15 minutes incubation in a solution of biotin, they were held for 10 minutes in PBS. This was followed by incubation in Streptavidin Peroxidase solution for 15 minutes. After being kept for 10 minutes in PBS, they were put in AEC (3 amino-9-etylcarbazole) chromogen for five minutes. They were then washed with distilled water. Sections were kept in Mayer's Hematoxylin for five minutes for contrast staining. They were then washed with running tap water and covered with ultramound. In preparations stained with $\beta$-catenin antibody, nuclear staining was taken as the basis for $\beta$-catenin positive staining and cytoplasmic staining was evaluated as negative. A total of 70 blocks were prepared for 5 groups established according to the classification of the World Health Organization (14).

The first group consisted of well-differentiated adenocarcinoma (WDA), the second group of moderately differentiated adenocarcinoma (MDA), the third group of poorly differentiated adenocarcinoma (PDA), the fourth group of signet ring cell adenocarcinoma (SRCA) and the fifth group of mucinous adenocarcinoma (MA) patients. While the WDA, MDA, PDA and MA study groups were consisted of 15 patients each, the SRCA patient group consisted of 10 patients, due to the lower number of cases. Following immunohistochemical staining with $\beta$-catenin antibody, the evaluation was graded according to the degree of staining as mild $(+)$, moderate $(++)$ and severe $(+++)$. Mean numbers of nuclei were determined by counting 100 cells from three selected areas. 1-30\% was evaluated as first grade, $30-60 \%$ as second grade and more than $60 \%$ as third grade. Lymph node metastases in patients were grouped as A: No lymph node metastases, B: 1 to 3 pericolic-perirectal lymph node metastases, C: 4 or more pericolic-perirectal lymph node metastases, and D: Lymph node metastasis along one or more major blood vessels.

Statistical Analysis: The Chi-square ( $\chi 2$ ) independence test was used to check the relationship between the factors 
affecting CRC prognosis. The Kruskal-Wallis test was used to determine whether the $\beta$-catenin stained cell numbers were different for each CRC prognostic factor. The MannWhitney $\mathrm{U}$ test was used for paired group comparisons. Following Bonferroni correction as $\alpha^{*}=\alpha / k=0.05 / 10=0.005$, the results were $\mathrm{k}: 10$ and $\alpha=0.005$. Evaluation was performed for degree of tumor differentiation, stage, lymph node metastasis, vascular invasion, tumor local spread and the number of nuclei stained. The relationship between the number of nuclei stained with $\beta$-catenin and antibodies in malignant tissues was evaluated with the Pearson correlation test. P values smaller than 0.001 were defined as very significant and values smaller than 0.05 as significant. The SPSS10.0 software was used for statistical calculations.

\section{RESULTS}

Of the cases, 15 (21.4\%) consisted of WDA, 15 (21.4\%) of MDA, 15 (21.4\%) of PDA, 15 (21.4\%) of MA, and 10 $(14.6 \%)$ of SRCA. The study was a retrospective study and survival analysis could not be performed for patients due to the short follow-up periods. However, it was found that decreased differentiation of the tumor increased the expression of $\beta$-catenin and there was a relationship between the groups created according to the differentiation level and the number of nuclei staining positively with $\beta$-catenin $(p<0.001)$. Nuclear staining was more intense in poorly differentiated tumors and there was a significant relationship between the differentiation of the tumor and the intensity of nuclear staining with $\beta$-catenin $(p<0.001)$. The relationship varied significantly from Group 1 to Group $3(p<0.001)$. While a significant relation was also found between Group 3 and Group 4 ( $\mathrm{p}=0.026)$, the relationship

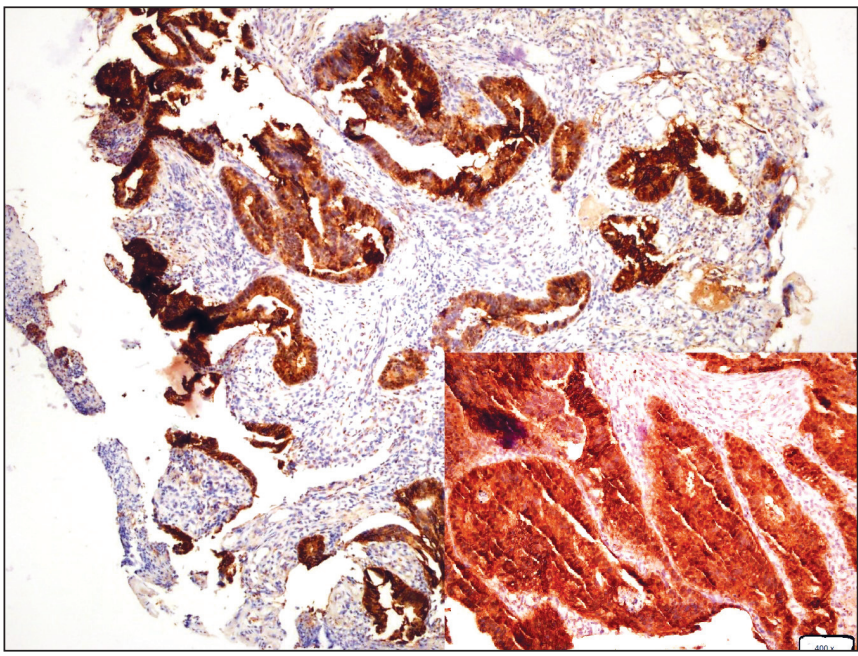

Figure 1: Well-differentiated adenocarcinoma stained with $\beta$-catenin $(\times 100)$. between Group 3 and Group 5, and Group 4 and Group 5 was not significant $(\mathrm{p}=0.309, \mathrm{p}=0.120)$ (Figure 1,2) (Table I).

There was a significant relationship between the differentiation of the tumor and nuclear staining with $\beta$-catenin with the number of positively stained nuclei increasing in poorly differentiated tumors (Figure 3,4) (Table II).

The relationship between the histologic grade of the tumor and the number of nuclei stained with $\beta$-catenin was also significant $(\mathrm{p}<0.001)$ (Table III).

The number of positively stained nuclei was higher in tumors with a high number of lymph node metastases and there was a significant relationship between $\beta$-catenin expression and lymph node metastasis $(\mathrm{p}<0.001)$ (Table IV).

When the relationship between tumor stage according to the TNM Classification and $\beta$-catenin expression was evaluated, there was a significant association $(p<0.001)$ between increased $\beta$-catenin expression and increasing stage $(\mathrm{p}<0.001)($ Table $\mathrm{V})$.

The relationship between vascular invasion and $\beta$-catenin expression was not found to be significant $(\mathrm{p}=0.152)$. However, a significant relationship was found between the diameter and size of the tumor and $\beta$-catenin expression $(\mathrm{r}=0.247, \mathrm{p}=0.035)(\mathrm{r}=0.464, \mathrm{p}<0.001)$.

\section{DISCUSSION}

CRC is one of the most common types of cancer. Globally 1,233,000 new cases were defined in 2008 and there were 608,000 deaths from the disease. It is estimated to be fourth in the world in terms of cancer mortality (15). Although

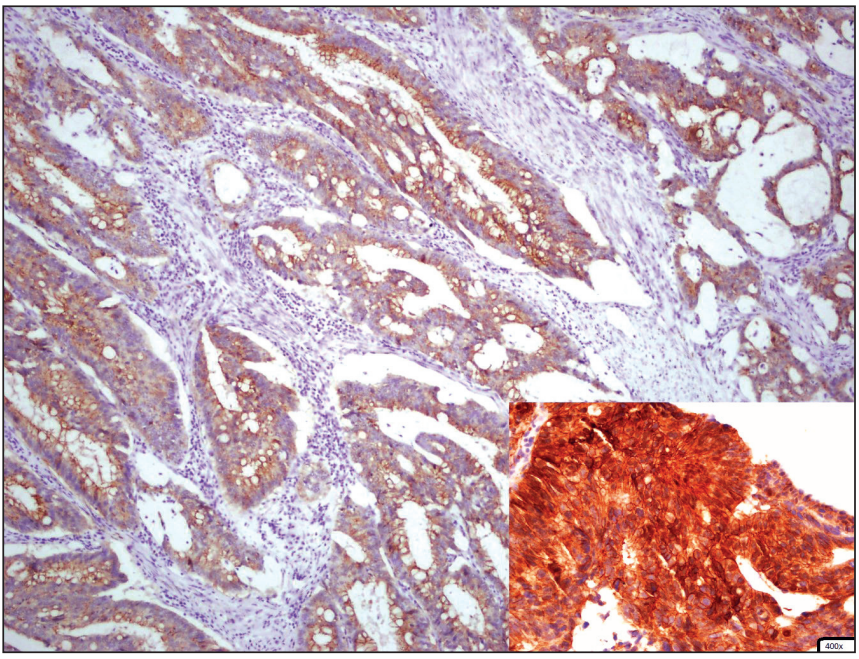

Figure 2: Moderately differentiated adenocarcinoma stained with $\beta$-catenin $(\times 100)$. 


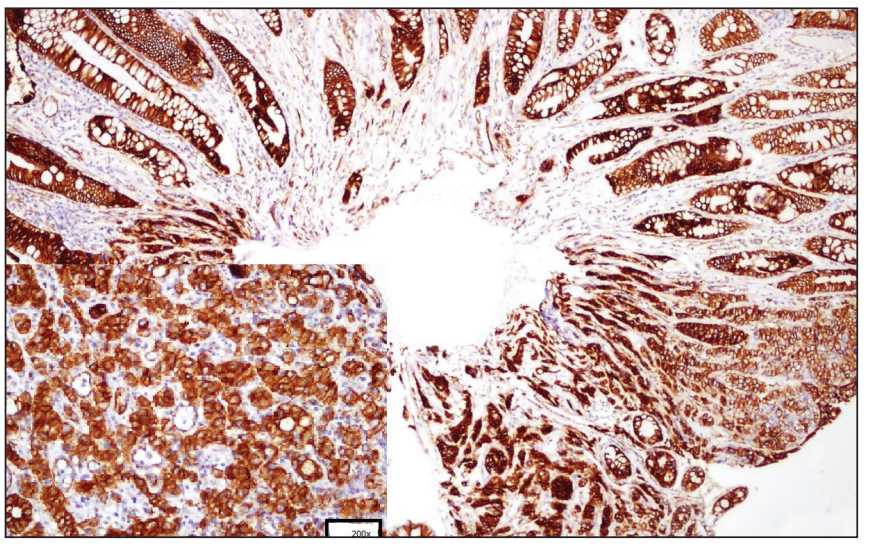

Figure 3: Poorly differentiated adenocarcinoma stained with $\beta$-catenin $(\times 100)$.

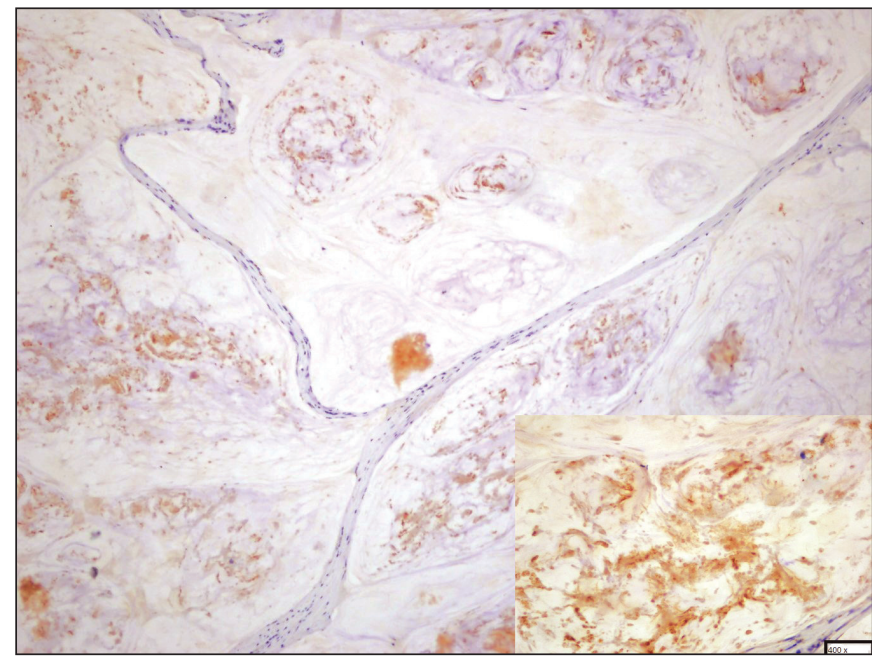

Figure 4: Mucinous adenocarcinoma stained with $\beta$-catenin $(\times 100)$.

Table I: Groups and the degree of positive staining with $\beta$-catenin

\begin{tabular}{|c|c|c|c|c|c|}
\hline & & ++ & +++ & Total & $\mathbf{p}$ \\
\hline Group 1 & $\mathrm{n}$ & 15 & & 15 & Group 1 - Group $20.000^{*}$ \\
\hline Group 2 & $\mathrm{n}$ & 15 & & 15 & Group 1 - Group $40.000^{*}$ \\
\hline Group 3 & $\mathrm{n}$ & 1 & 14 & 15 & Group 1 - Group 5 0.000* \\
\hline Group 4 & $\mathrm{n}$ & & 10 & 10 & Group 2 - Group $30.000^{*}$ \\
\hline Group 5 & $\mathrm{n}$ & & 15 & 15 & Group 2 - Group 5 0.000* \\
\hline Total & $\mathrm{n}$ & 31 & 39 & 70 & $\begin{array}{l}\text { Group } 3 \text { - Group } 4 \text { 1.000+ } \\
\text { Group } 3 \text { - Group } 51.000+\end{array}$ \\
\hline
\end{tabular}

${ }^{*} \mathrm{p}<0.001,+\mathrm{p}>0.001$

(Group 1: Well-differentiated adenocarcinoma, Group 2: Moderately differentiated adenocarcinoma, Group 3: Poorly differentiated adenocarcinoma, Group 4: Signet ring cell adenocarcinoma, Group 5: Mucinous adenocarcinoma)

$\mathrm{CRC}$ is defined as a disease of Western society, in recent years it is reported to be the most common type of cancer of the gastrointestinal system in the Asia-Pacific region (16). The CRC incidence is seventh among cancers in our country according to the 2005 data of the Republic of Turkey Ministry of Health, Department of Cancer Control (17). Its etiology is complex and includes environmental and genetic factors (18). Extensive studies have been conducted on the carcinoma development mechanism in CRC. CRC pathogenesis is an important process. It can start as a benign polyp and turn into adenoma and carcinoma later. During this period, the tumor suppressor genes and oncogenes lose their characteristics and mutate respectively (11). Many factors play a role in each step of carcinogenesis.
In addition, the steps must follow certain sequence for the development of the tumor. The APC gene is mutated at the first step. The cell cycle may become uncontrolled with both alleles of the APC gene losing function. Genetic mutations occurring in any of the four genes related to the DNA repair mechanism is responsible for the HNPCC familial syndrome (19).

Many studies have shown lack of E-cadherin secretion in human cancers. In general, this is associated with differentiation and invasion $(20,21)$. According to Cowley et al, E-cadherin is significantly decreased in primary gastric carcinoma compared to the normal mucosa and a serious relationship is reported between poor secretion and poor differentiation. The same study associated abnormal 
Table II: Groups and number of nuclei positively stained with $\beta$-catenin

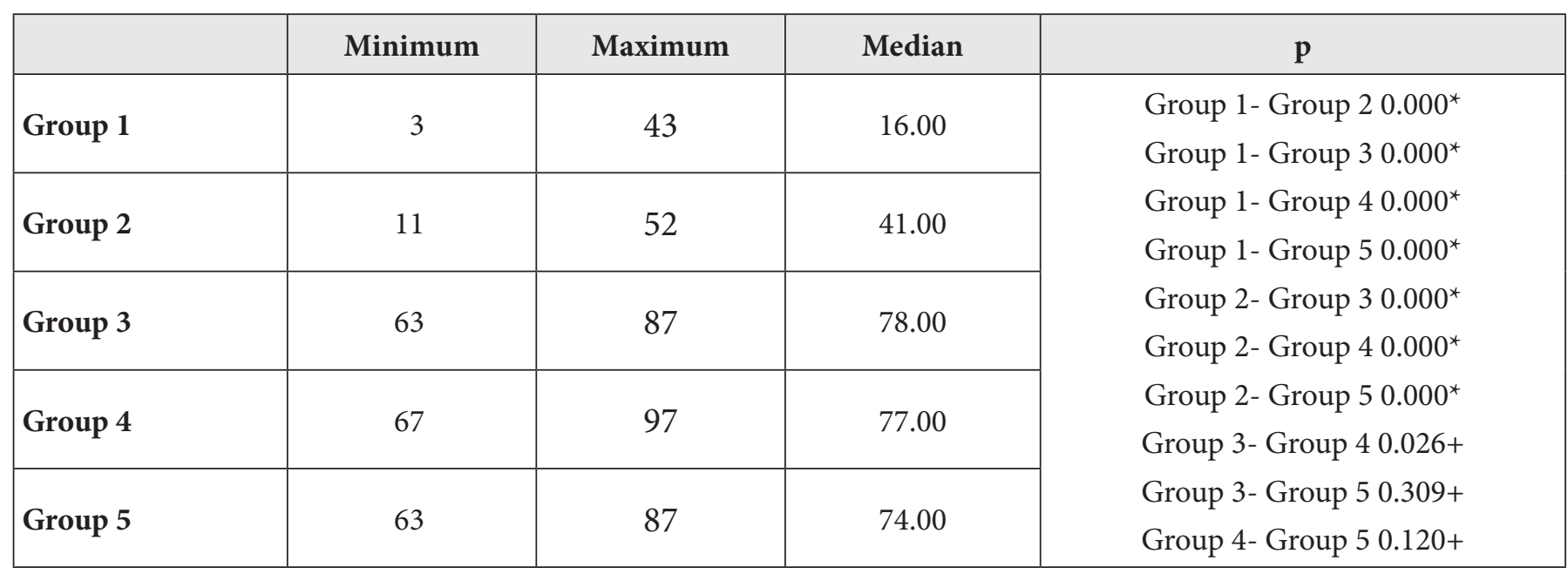

${ }^{\star} \mathrm{p}<0.001,+\mathrm{p}>0.001$

(Group 1: Well-differentiated adenocarcinoma, Group 2: Moderately differentiated adenocarcinoma, Group 3: Poorly differentiated adenocarcinoma, Group 4: Signet ring cell adenocarcinoma, Group 5: Mucinous adenocarcinoma)

Table III: Relationship between histological grade and the number of nuclei stained positively with $\beta$-catenin

\begin{tabular}{|c|c|c|c|c|}
\hline $\begin{array}{c}\text { Histological } \\
\text { Degree }\end{array}$ & $\mathbf{n}$ & Minimum & Maximum & Median \\
\hline WDA & 15 & 3 & 43 & 16 \\
\hline MDA & 15 & 11 & 52 & 41 \\
\hline PDA & 40 & 63 & 97 & 76 \\
\hline Total & 70 & 3 & 97 & 54 \\
\hline
\end{tabular}

WDA: Well-differentiated adenocarcinoma, MDA: Moderately differentiated adenocarcinoma, PDA: Poorly differentiated adenocarcinoma.

Table V: Relationship between tumor stage and the number of nuclei stained positively with $\beta$-catenin

\begin{tabular}{|l|r|c|c|c|}
\hline Tumor Stage & $\mathbf{n}$ & $\begin{array}{c}\text { Minimum } \\
\text { NN }\end{array}$ & $\begin{array}{c}\text { Maximum } \\
\text { NN }\end{array}$ & $\begin{array}{c}\text { Median } \\
\text { NN }\end{array}$ \\
\hline Stage 1 & 6 & 3 & 42 & 18 \\
\hline Stage 2 & 13 & 3 & 95 & 44 \\
\hline Stage 3 & 44 & 8 & 95 & 75 \\
\hline Stage 4 & 7 & 8 & 97 & 83 \\
\hline Total & 70 & 3 & 97 & 53 \\
\hline
\end{tabular}

E-cadherin secretion with a poor prognosis (22). A study found a $47.7 \%, 44.6 \%$, and $61.5 \%$ rate of abnormality in $\alpha$, $\beta, \gamma$-catenin secretions respectively in patients with gastric carcinoma (23). Another study in stomach cancers found strong nuclear $\beta$-catenin staining in $29(58 \%)$ of the series of 50 cases (24). Jolanta Czyzewska et al. found a significant
Table IV: Number of nuclei (NN)

\begin{tabular}{|c|r|c|c|c|}
\hline $\begin{array}{c}\text { Metastatic } \\
\text { Lymph Node }\end{array}$ & n & $\begin{array}{c}\text { Minimum } \\
\text { NN }\end{array}$ & $\begin{array}{c}\text { Maximum } \\
\text { NN }\end{array}$ & $\begin{array}{c}\text { Median } \\
\text { NN }\end{array}$ \\
\hline A & 17 & 3 & 95 & 23 \\
\hline B & 12 & 7 & 87 & 49 \\
\hline C & 35 & 13 & 94 & 69 \\
\hline D & 6 & 8 & 97 & 83 \\
\hline Total & 70 & 3 & 97 & 56 \\
\hline
\end{tabular}

A: No lymph node metastasis, B: 1-3 pericolic-perirectal lymph node metastases, C: 4 or more pericolic-perirectal lymph node metastases, D: 1 or more lymph node metastases along major vascular routes.

relationship between tumor location, depth and lymph node metastasis in 91 patients with gastric cancer (25). We found an abnormality in $\beta$-catenin secretion in $95.7 \%$ of our cases. We also found a significant relationship between differentiation and abnormal $\beta$-catenin secretion.

Yu-Jun Ji et al. studied 47 patients with pancreatic adenocarcinoma and 12 normal patients. Abnormal E-cadherin, and $\alpha$ and $\beta$-catenin secretion was found in $53 \%, 61 \%$, and $68 \%$ respectively in the tissues of 47 patients with pancreatic carcinoma. The abnormal secretion of E-cadherin and $\alpha$-catenin was found to be associated with lymph node and liver metastasis, and differentiation while abnormal $\beta$-catenin secretion was associated with lymph node and liver metastases. However, abnormal secretion of E-cadherin, and $\alpha$ and $\beta$-catenin was found not to be associated with tumor size, invasion and survival (26). We observed abnormal $\beta$-catenin secretion to be associated 
with lymph node metastasis, tumor size and local invasion in our study. However, we could not find a significant relationship with vascular invasion.

A study on a series of 280 cases showed a significant relationship between nuclear translocation of $\beta$-catenin and development phases of CRC. $\beta$-catenin translocation was found in $8 \%$ of non-adenomatous polyps, $91 \%$ of adenomas, and $100 \%$ of adenocarcinomas. The same study reported the degree of cytoplasmic and membranous staining in addition to nuclear staining to be parallel to tumor stages and the degree of nuclear staining and lymph node metastasis to also show parallelism (27). We obtained similar results in our study. Another study reported tumor metastases to increase due to E-cadherin function loss and disruption of the between catenins and the cell skeleton with an important link between these events and local invasion (28). We obtained similar results in our study.

In the light of all this information we can say that $\beta$-catenin has an obvious role in colorectal carcinogenesis due to the functions of $\beta$-catenin in the cell and its relationship with the APC gene and cell functions. The intercellular relationships are degraded due to the function loss of $\beta$-catenin especially in advanced stage tumors spilling to the serosa and reaching regional lymph nodes. The details and contribution of this relationship to clinical outcomes were explained. B-catenin which is a prognostic factor appears to be closely associated with colorectal carcinogenesis of nuclear translocation.

\section{REFERENCES}

1. Jemal A, Siegel R, Ward E, Hao Y, Xu J, Murray T, Thun MJ: Cancer statistics, 2008. CA Cancer J Clin 2008, 58:71-96

2. Parkin DM, Bray F, Ferlay J, Pisani P: Global cancer statistics 2002. CA Cancer J Clin 2005, 5:74-108

3. Karaca Ö, Ertekin T, Canöz Ö, Hacıalioğulları M, Ekinci N, Elmalı F, Üger H: 1,2-Dimetilhidrazin ile Balb/C türü farelerde deneysel kolon kanserinin indüklenmesi. Turkiye Klinikleri J Med Sci 2010, 30: 1015-1024

4. Kinney TP, Merel N, Hart J, Joseph L, Waxman I: Microsatellite analysis of sporadic flat and depressed lesions of the colon. Dig Dis Sci 2005, 50:327-330

5. Nursal TZ, Hamaloğlu E, Enünlï T: Surgical treatment of elderly patients with colon cancer. Turkish Journal of Geriatrics 1998, 2:89-92

6. Cheng $\boldsymbol{H}$, Liang $\boldsymbol{H}$, Qin $Y$, Liu $Y$ : Nuclear beta-catenin overexpression in metastatic sentinel lymph node is associated with synchronous liver metastasis in colorectal cancer. Diagn Pathol 2011, 6:109

7. Akiyama T: Wnt/b-catenin signaling, Mini Review. Cytokine Growth Factor Rev 2000, 11: 273-282
8. Chandra SH, Wacker I, Appelt UK, Behrens J, Schneikert J: A common role for various human truncated adenomatous polyposis col isoforms in the control of Beta-Catenin activity and cell Proliferation. PLoS ONE 2012, 7:34479

9. MacDonald BT, Tamai K, He X: Wnt/beta-catenin signaling: Components, mechanisms, and diseases. Dev Cell 2009, 17:9-26

10. Fearnhead NS, Britton MP, Bodmer WF: The ABC of APC. Hum Mol Genet 2000, 10: 721-733

11. Kinzler KW, Vogelstein B: Lessons from hereditary colorectal cancer. Cell 1996, 87:159-170

12. Pollard P, Deheragoda M, Segditsas S, Lewis A, Rowan A, Howarth K, Willis L, Nye E, McCart A, Mandir N, Silver A, Goodlad R, Stamp G, Cockman M, East P, Spencer-Dene B, Poulsom R, Wright N, Tomlinson I: The Apc 1322T mouse develops severe polyposis associated with submaximal nuclear beta-catenin expression. Gastroenterology 2009, 136: 2204-2213

13. Konsavage WM Jr, Kyler SL, Rennoll SA, Jin G, Yochum GS: $\mathrm{Wnt} / \mathrm{B}$-catenin signaling regulates Yes-associated protein (YAP) gene expression in colorectal carcinoma cells. J Biol Chem 2012, 287:11730-91173

14. Hamilton SR, Aaltonen LA: Pathology and Genetics of tumours of the digestive system. World Health Organization classification of tumours. IARC Press, Lyon, 2000

15. Stanczak A, Stec R, Bodnar L, Olszewski W, Cichowicz M, Kozlowski W, Szczylik C, Pietrucha T, Wieczorek M, LamparskaPrzybysz M: Prognostic significance of Wnt-1, $\beta$-catenin and E-cadherin expression in advanced colorectal carcinoma. Pathol Oncol Res 2011, 17:955-963

16. Sung JY, Lau YW, Goh KL, Leung WK: Increasing incidence of colorectal cancer in Asia: Implications for screening. Lancet Oncol 2005, 6:871-876

17. Özdemir Y, Özdemir S, Filiz Aİ, Sücüllü İ, Kurt Y, Yıldız M: Prognostic value of lymph node ratio for colorectal cancer. Balkan Med J 2011, 28:86-90

18. Cherry LM: The genetic etiology of familial and nonfamilial colorectal cancer. Proc (Bayl Univ Med Cent) 2011, 24:139-141

19. Patıroğlu TE: Neoplasia. İn Kumar V, Cotran RS, Robbıns SL. (Eds): Temel Patoloji (Basic Pathology): Translation Çevikbaş U. Temel Patoloji. İstanbul, Nobel Tip Kitapevleri, 2000, 508-510

20. Brabletz T, Herrmann K, Jung A, Faller G, Kirchner T: Expression of Nuclear $\beta$-catenin and $c$-myc is correlated with tumor size but not with proliferative activitiy of colorectaladenomas. Am J Pathol 2000, 156:865-870

21. Bondı J, Bukholm G, Nesland JM, Bukholm IRK: Expression of non-membranous $\beta$-catenin and $\gamma$-catenin c-myc and cyclin D1 in relation to patient outcome in human colon adenocarsinomas. APMIS 2004, 112:49-56

22. Cowley GP, Smith ME: Modulation of E-cadherin expression and morphological phenotype in the intravascular component of adenocarcinomas. Int J Cancer 1995, 60:325-329

23. Joo YE, Park CS, Kim HS, Choi SK, Rew JS, Kim SJ: Prognostic significance of E-cadherin/catenin complex expression in gastric cancer. J Korean Med Sci 2000,15:655-666 
24. Zhang F, Tang JM, Wang L, Shen JY, Zheng L, Wu PP, Zhang $M$, Yan $Z W$ : Detection of $\beta$-catenin, gastrokine- 2 and embryonic stem cell expressed ras in gastric cancers. Int J Clin Exp Pathol 2010, 3:782-791

25. Czyzewska J, Guzińska-Ustymowicz K, Ustymowicz M, Pryczynicz A, Kemona A: The expression of E-cadherincatenin complex in patients with advanced gastric cancer: Role in formation of metastasis. Folia Histochem Cytobiol 2010, 48:37-45

26. Li YJ, Ji XR: Relationship between expression of E-cadherin/ catenin complex and clinicopathologic characteristics of pancreatic cancer. World J Gastroenterol 2003, 9:368-372

27. Wong SC, Lo ES, Lee KC, Chan JK, Hsiao WL: Prognostic and diagnostic significance of $\beta$-catenin Nuklear immunostaining in colorectal cancer. Clin Cancer Res 2004, 10:1401-1408

28. Munné A, Fabre M, Mariñoso ML, Gallén M, Real FX: Nuclear beta-catenin in colorectal tumors: to freeze or not to freeze? Colon Cancer Team at IMAS. J Histochem Cytochem 1999, 47:1089-1094 